\title{
Experimental and Simulation Study of Small Scale PV Powered Photobioreactor for Nannochloropsis oculata Cultivation
}

\author{
Bambang Susilo, Nilam Fitri Widyaningrum, Mochamad Bagus Hermanto, Dimas Firmanda Al Riza* \\ Agricultural Engineering Department, University of Brawijaya, Jl. Veteran, Malang, 65145, Indonesia \\ E-mail: *dimasfirmanda@ub.ac.id
}

\begin{abstract}
Microalgae has become promising third generation source of biodiesel material recently. One of the methods that is used for microalgae cultivation is by using photobioreactor. The advantages in using photobioreactor to cultivate microalgae are the easiness to control optimum growth parameters and to protect culture from external contamination. However, to run a photobioreactor, considerable amount of energy is required in the form of electricity. To achieve zero emission production, renewable energy system such as PV system can be used to run the photobioreactor. In this research a PV system has been used to supply energy of a small scale photobioreactor for Nannochloropsis oculata cultivation. The experimental setup were operated for one cycle cultivation that takes about seven days long. $500 \mathrm{Wp} \mathrm{PV}$ panel and 400 Ah battery capacity of $12 \mathrm{~V}$ PV system were used. It is shown that the system can supply the required energy during the cultivation time. Yet, the SoC of battery shown decreasing level during operation. It is revealed that the system that is used for experiment need to be redesign and simulation using TRNSYS is used to test the recommended system setup.
\end{abstract}

Keywords - Microalgae, TRNSYS, system design, renewable energy.

\section{INTRODUCTION}

To overcome energy crisis that is threaten our future, energy diversification is important especially from renewable energy resources. Biomass energy sources such as briquet, biogass, bioethanol, and biodiesel are potentially replaced fossil fuel. Biodiesel could replace liquid fossil fuel particularly diesel fuel that is greatly used in transportation. Since the properties of Biodiesel that is resembled diesel fuel, it can be used with less machine modification [1].

Not all species of microalgae appropriate for biodiesel production, it is depend on the type and amount of oil that is produced by it [2]. Total lipid percentage such as neutral lipid, glycolipid, and phospholipid are vary for each species of microalgae [3]. From several species listed in Table 1, Nannochloropsis sp. are categorized as microalgae with high content of oil. Furthermore, Nannochloropsis sp. can be growth with high cell density (50 and $27.5 \mathrm{~g} / \mathrm{L})$ in an autotrophic growth condition and produce high lipid content (52\% and 46\%) [4].

Microalgae can be cultivated through open system such as open pond or closed system such as photobioreactor [5]. Open pond cultivation system are generally used nowadays since the cost to build it relatively cheaper than other system. Even though the cost of making open pond system is cheaper, contamination from other species of algae or even bacteria are likely occurs. Other disadvantages of open pond system is the area needed will be wider since the depth of the water should be limited so sunlight can pass through the water and evenly distributed. Cultivation with closed system (without light) only suitable for several species of microalgae (heterotrophic microorganism) and not as efficient as photosyntetic process (photoautotrophic). Microalgae cultivation system using photobioreactor has several advantages i.e. the ability to control optimum growth parameters, protection from culture contamination, and area efficiency by using vertical system. However, installation and operational cost might be more expensive.

In photobioreactor operation power supply are needed to supply energy for pump, monitoring and control system, and other required supporting devices. If this kind of energy source are come from conventional grid electricity it would not be a pure renewable energy production system. The use of solar energy (photovoltaic) to supply photobioreactor system is one of the solution to achieve production system that is purely come from renewable energy. From this research it is expected that data related to load profile of small scale photobioreactor can be obtained especially for operation in tropical country climate (Indonesia). In addition, the data that is obtained from this research hopefully would be used as input data for photovoltaic (PV) power system sizing for photobioreactor operation and for system simulation. It is expected from this research PV 
powered photobioreactor model can be used to predict and observe the behavior of the real system so it can simulate the real condition to achieve reliable system. Model that is developed in this research are validated using experimental data for small scale photobioreactor system.

\section{MATERIALS AND METHOD}

\section{A. PV System design using PSH Method}

To design standalone PV system using PSH method, firstly, solar energy potential for the location and daily electricity load need to be known. Photobioreactor prototype that was used in this research using a water pump with 60 Watt power and operational time of 24 hours. From this data total daily electricity power $\left(P_{\text {total }}\right)$ for the prototype is about $1440 \mathrm{Wh} /$ day. Solar energy potential for East Java area can be found on global solar radiation map, i.e. about 4.5 $\mathrm{kWh} /$ day, this value equal to 4.5 PSH.

By using the above data PV panel and battery capacity can be calculated using the following equation:

$$
\begin{aligned}
P_{P V} & =\frac{P_{\text {load }}}{P S H \times \eta_{\text {system }}} \\
C_{\text {bat }} & =\frac{P_{\text {load }} \times N_{a}}{D o D \times V_{\text {system }} \times \eta_{\text {system }}}
\end{aligned}
$$

$P_{P V} \quad=$ PV panel capacity $(\mathrm{Wp})$

$P_{\text {load }} \quad=$ Daily electricity load

$P S H \quad=$ Peak Sun Hour

$\eta_{\text {system }}=$ System efficiency

$C_{\text {bat }} \quad=$ Battery capacity

DoD $\quad=$ Depth of Discharge

$N_{a} \quad=$ Autonomy day number

$V_{\text {system }}=$ System voltage

Other parameters such as system efficiency, system voltage and DoD are presented in Table 1.

TABLE I

PARAMETERS VALUE FOR CALCULATION

\begin{tabular}{|c|l|c|c|}
\hline No. & \multicolumn{1}{|c|}{ Parameters } & Value & Unit \\
\hline 1 & System efficiency & 90 & $\%$ \\
\hline 2 & System Voltage & 12 & Volt \\
\hline 3 & DoD & 50 & $\%$ \\
\hline
\end{tabular}

The value of system efficiency parameter is the total efficiency include energy lost because of cable connecion, dust factor, inverter efficiency and charging efficiency. System voltage of $12 \mathrm{~V}$ was chosen for small scale system (under $1 \mathrm{kWp}$ ), while for DoD, the "sweet spot" value of $50 \%$ was used for a trade off between optimum energy consumption and battery age [6]. From the calculation and sizing curve of PV panel and battery capacity it can be found for 1440Wh daily electricity load and PSH of 4, the suitable PV system configuration consist of $457 \mathrm{Wp} \mathrm{PV}$ panel and 1028Ah battery capacity for $12 \mathrm{~V}$ system. The value of PV panel and battery capacity then adjusted by rounding the number up or diwn so the capacity meet the available PV panel in the market. It is reccommended to round the number up so the capacity would not be under-design. Finally, the recommended configuration are $500 \mathrm{Wp} \mathrm{PV}$ panel with $1000 \mathrm{Ah}$ battery for $12 \mathrm{~V}$ system.

\section{B. Experimental Setup (Photobioreactor, PV System, and Culture)}

For this research case, electricity load is electricity energy that is needed by photobioreactor system. Photobioreactor electricity load actually consist of circulation system power (pump), monitoring and control, and also supporting devices. However in this research, small scale photobioreactor that only needed circulation and aeration system are used. So, operational characteristic of photobioreactor electricity load depend on pump operation. Fig. 1 shows experimental set up for PV powered small scale vertical photobioreactor.

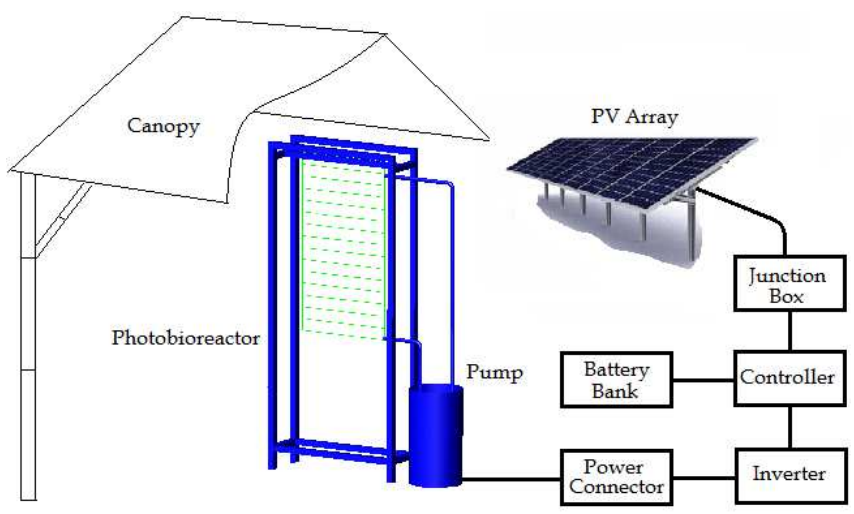

Fig. 1 Experimental setup

PV system are installed to supply power of aerator and pump. PV system specification for the experiment are presented as follow:

TABLE II

PV SYSTEM SPECIFICATION

\begin{tabular}{|l|l|l|}
\hline No. & \multicolumn{1}{|c|}{ Item } & \multicolumn{1}{c|}{ Specification } \\
\hline 1. & PV Panel & $400 \mathrm{Wp}$ (minimum) \\
\hline 2. & Battery & $400 \mathrm{Ah}, 12 \mathrm{~V}$ (minimum) \\
\hline 3. & Controller & $30 \mathrm{~A}$ \\
\hline 4. & Inverter & $500 \mathrm{~W}$ \\
\hline
\end{tabular}

Small scale vertical photobioreactor has been developed with PE plastic as the material. This photobioreactor has been tested to cultivate Nannochloropsis oculata with grid electricity as the power source [7]. This photobioreactor was operated outdoor with canopy to avoid direct sunlight that can induce photoinhibition. This photobioreactor use 60 Watt pump with 24 hours daily operation time. Total energy used for this photobioreactor prototype $\left(P_{\text {total }}\right)$ is about 1440 Wh per-day.

Microalgae seeds used in this research are Nannochloropsis oculata pure culture. $1 \mathrm{~mL}$ Walne fertilizer are used for each Liter of culture. N. Oculata culture preparation consist of several steps: Sealed plastic are hanged on steel frame as shown in Fig.1; water are circulated through pipe and photobioreactor plastic by using submerged pump; sterilized drum with sumerged pump inside are filled with sea water; $1 \mathrm{~mL}$ Walne fertilizer are 
mixed with 1 Liter of sea water and left \pm 5 minutes until homogen culture are obtained.

\section{System model in TRNSYS}

To produce reliable PV system in supplying required energy for photobioreactor, PV components sizing are required. Sizing method using Peak Sun Hour (PSH) can be used for instant design. The result of this design then can be tested using PV model simulation in TRNSYS software.

PV system model that is used for simulation in this research are based on standalone PV system model that is developed by Al Riza, 2011 using TRNSYS 16. The model will also be validated using experimental data from this research. Further analysis can be carried out by using simulation with full year meteorological data.

\section{RESULTS AND DISCUSSION}

\section{A. Photobioreactor performances: Growth of Microalgae}

It is revealed from from the research that flow rate of the culture affect the growth of microalgae. $N$. oculata density are decreased as increasing of flow rate as can be seen in Fig. 2. Andriyono (2001), explained that illumination periodic take an effect on synthesis process of organic material in photosynthesis since only with required energy the process will be running smoothly [9]. Flow rate also will affect the amount of sunlight received by the culture, less sunlight will cause unoptimal photosynthesis process whereas too high sunlight intensity will lead to photoinhibition phenomenon.

Hermanto et al. (2011) who's used flow rate of 0.6 $\mathrm{L} /$ minutes achieved cell density of $3293 \times 104$ cell $/ \mathrm{mL}$ for Nannochloropsis oculata species. The differences with this research result is suspected because of water temperature and sunlight amount during the experiment. It is also supported by Fabregas et al. (1986) in Sutomo (2005) explanation that salinity, $\mathrm{pH}$, nutrition, temperature, carbon source and light affect phytoplancton growth [10]. Fig. 3 shows photobioreactor during operation.
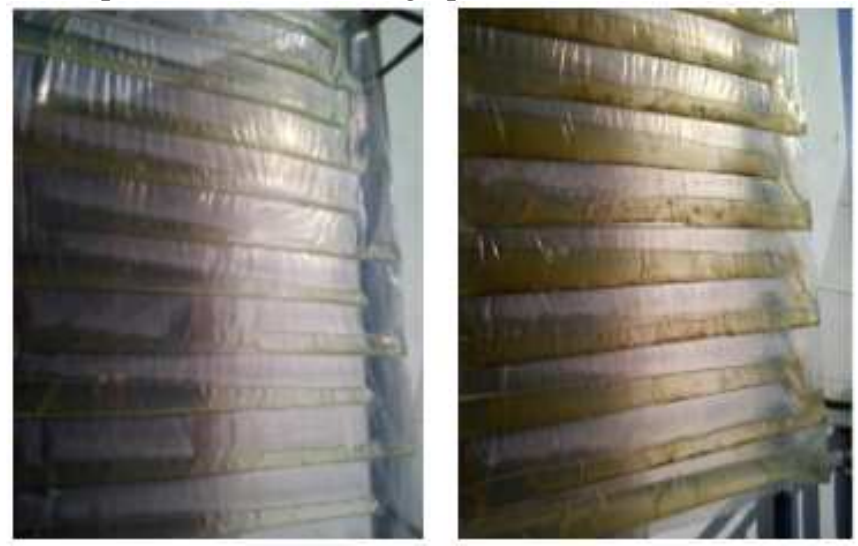

Fig. 3. Photobioreactor operation

\section{B. Photobioreactor performances: Water parameter dynamic}

$\mathrm{pH}$ value during experiment are in the normal range for Nannochloropsis oculata growth, this microalgae species are well growth in $\mathrm{pH}$ range of 7.0-9.5 [11, 12, and 13]. $\mathrm{pH}$ value monitoring results are presented in Fig. 4. From the experiment treatment each flow rate result in different $\mathrm{pH}$ value. The best $\mathrm{pH}$ value range are obtained with 0.8 $\mathrm{L} /$ minutes flow rate conditon. $\mathrm{pH}$ value obtained by this condition ranged from 7.06-8.06.

From the measurement, it is revealed that base $\mathrm{pH}$ condition result in lower growth rate of microalgae. This condition has also been explained by De La Noue dan De paw (1988), that $\mathrm{pH}$ value of the culture will affect biological ability of algae in using nutrient in the culture [14]. High $\mathrm{pH}$ value can reduce photosythesis activity of microalgae. Eventhough Walne fertilizer has a complete nutrient composition, if photosynthesis process are hung up the cell growth will be halted and lead to cell mortality.

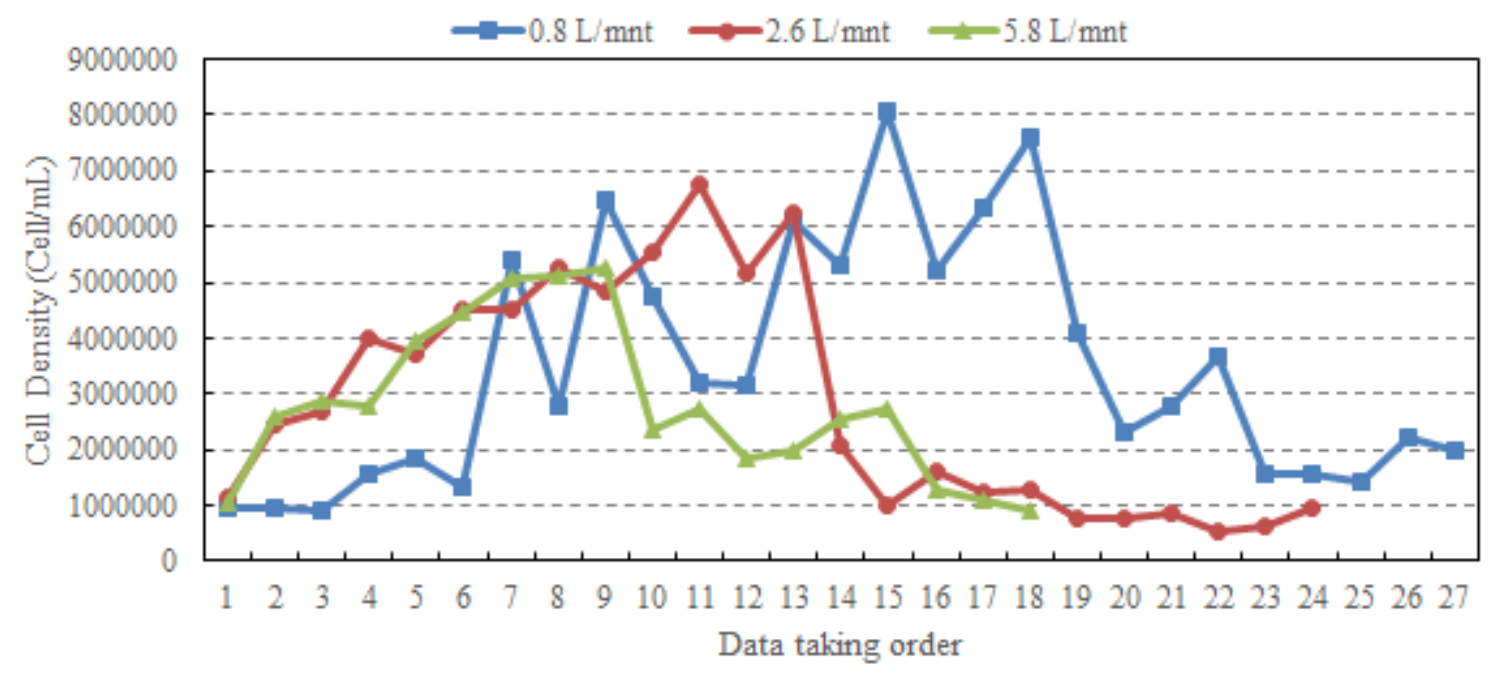

Fig. 2 Nannochloropsis oculata cell density during experiment 


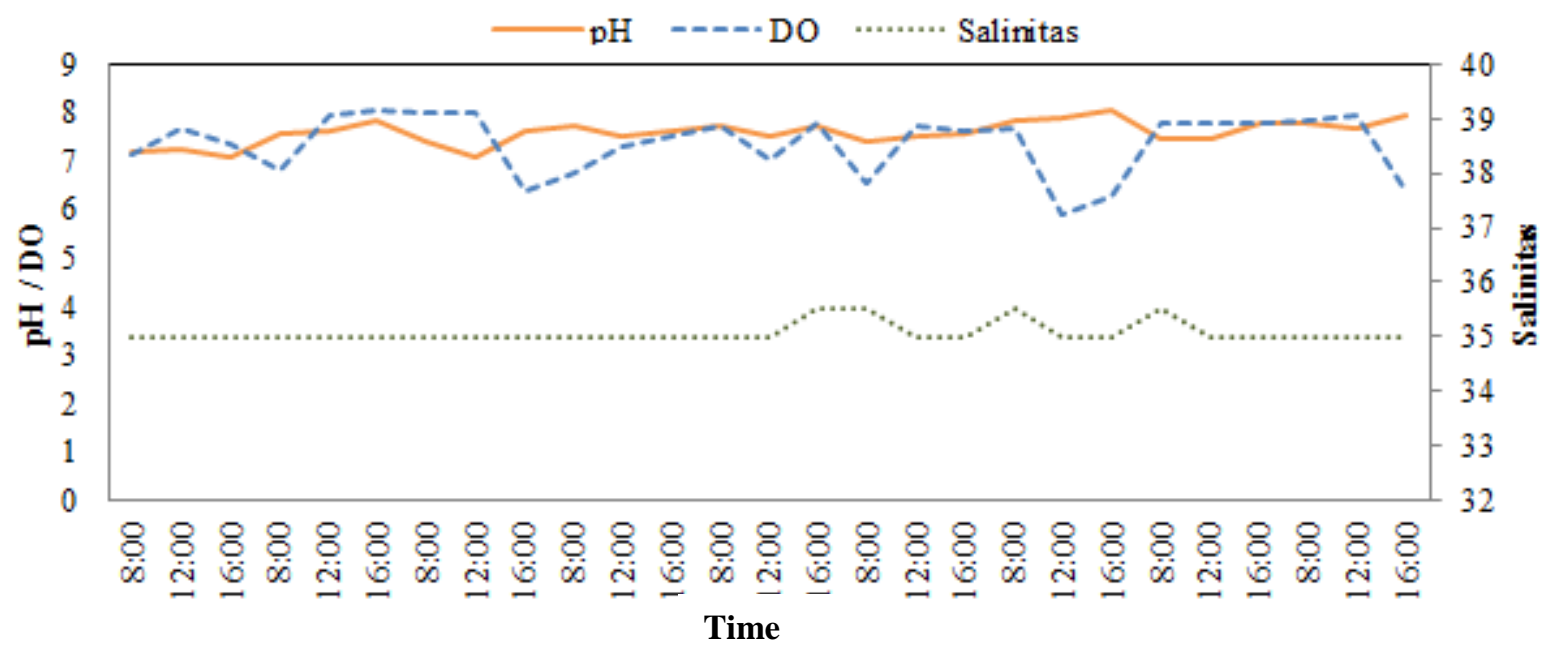

Fig. 4 pH, DO, and Salinity measured during experiment

Beside of that, Barus (2002), explained that culture condition that is too acid or too base are not good for microalgae growth since metabolism and respiration process will be disturbed [15].

Dissolved oxygen value as can be seen in Fig. 4 are relatively in the stable range between $6.17-8.23 \mathrm{mg} / \mathrm{L}$. It is found that oxygen received and released by the culture relatively in normal condition. Oxygen diffussion process are maintained by using aerator. Salinity value during experiment also found to be stable about $35-35.5$ o/oo for 0.8 $\mathrm{L} /$ minutes treatment and $35 \mathrm{o} / \mathrm{oo}$ for 2.6, 5.8 L/minutes dan control condition. It means that evaporation of the culture is minimum since it is a closed system that is placed under a canopy. Evaporation can be occured due to heat of lamp during night (artificial lighting) or sunlight. Evaporation will reduce the amount of water in the culture and increase the salinity value [16]. Optimum salinity range value for Nannochloropsis oculata are between 25-35 ppt [17].

It is revealed that salinity and $\mathrm{pH}$ value of the culture are correlated, high $\mathrm{pH}$ value affect microalgae photosynthesis activity. So, the microalgae growth rate are affected by $\mathrm{pH}$ value of nutrient that lead to limitation of microalgae ability in using culture nutrient in their metabolism. The amount of nutrient that is unused during the process and organic metabolism residue give rise to salinity value. Higher $\mathrm{pH}$ value cause increasing of salinity as microalgae growing. The microalgae are growth for about 8 days, until it reach constant growth phase or even mortal phase.

\section{Energy balance analysis of the system}

Fig. 5 shows the results of PV system power measurement during experiment. The input energy available during the day and there are no energy input during night whilst the energy output for pump and aerator occurs full day. Electricity load constantly used for 24 hours per day with total power of 60 Watt. It can be seen that output energy during the night relatively constant. Load profile changes in the graphic estimated related with sensor accuracy and pump rotation load that is little bit fluctuated. During the day there are energy input from solar irradiation and output for electricity load, it is shown that there are surplus energy during the day that will be stored in the battery to supplye energy for the system during the night. So beside supplying energy for the load the PV system also charging the battery that used to save energy for night.

It can be seen in Fig. 6 that battery voltages are vary in accordance with the energy level condition and state of charging and discharging. Battery voltage can be used as an indicator for state of charge (SOC) of the battery. During the night, battery in the condition of discharging so battery voltage constantly decreasing. Battery decreasing slope are depend on the amount of load In this experiment, since the electricity load are constant, the decreasing rate of battery voltage (slope) also found to be constant.

PSH value from first day to the last day of experiment are $4.3,4.5,3.5,4.8,3.0,4.8,1.5$, and 4.5 consecutively. On the $3^{\text {rd }}, 5^{\text {th }}$, and $7^{\text {th }}$ day can be seen that solar irradiation are low with PSH value under the designed PSH value. This condition cause system can not supply and charge battery to reach the initial state of charge level. This lead to the decreasing of battery voltage during the experiment. Battery voltage which indicate the energy level of the battery will increase if there are energy surplus of the system which is reached under PSH value more than 4.5. However, generally, based on measurement data, PV system performance are relatively good since it can supply energy until the experiment is over. Overall system performance should be further analysed with longer time of PVphotobioreactor running. It can be done with simulation using full year meteorological data. 


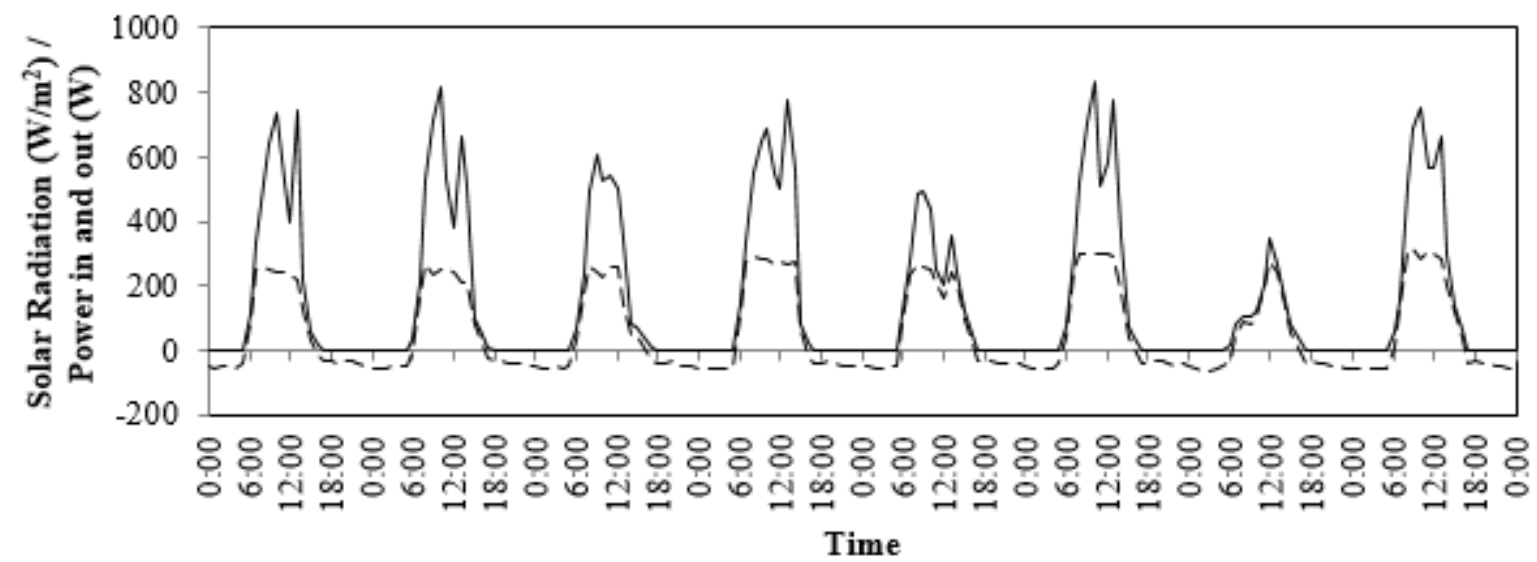

Fig. 5 Energy input and output of PV-Photobioreactor system during the experiment

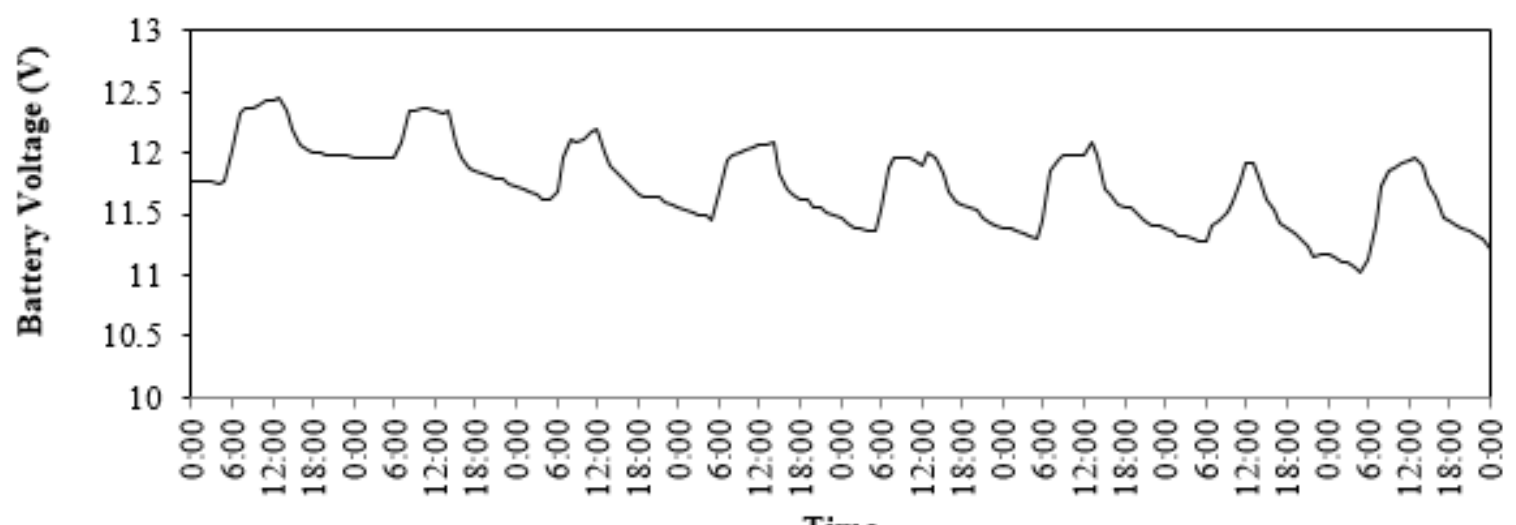

Time

Fig. 6 Battery Voltage monitoring during the experiment

Based on observation of fat content of Nannochloropsis oculata during experiment, it has been found that on the last day of experiment fat content of the microalgae reach $3.56 \%$. At the peak growth curve, fat content of the microalgae are about $17.89 \%$ with light intensity between 1000-2000 lux. Previous research relating to fat content of Nannochloropsis oculata is about $4.29 \%$ [16], and other research state that the fat content of Nannochloropsis oculata can reach value of $31-68 \%$ depend on culture conditon. Harsanto (2009) conducted Nannochloropsis oculata outdoor bulk culture at light intensity of 9000 lux, resulting total fat content of $36 \%$.

Fat content of microalgae are increasing under condition of low nitrogen [16]. In Rizky (2010), Nitrogen source as a culture component are come from urea as a source of organic nitrogen. Nitrogen is a macro nutrient element that affect metabolism process of microalgae such as transport, catabolism, asimilation, and especially protein biosynthesis since enzymatic reaction allows the conversion of fat so indirectly Nitrogen content will affect the fat content. Low Nitrogen concentration will increase fat content, but cell concentration will be realtively low.
From the experiment data calculation total energy Input needed for the photobioreactor operation was $1.516 \mathrm{MJ} / \mathrm{kg}$ of microalgae with output energy from microalgae of 1.750 $\mathrm{MJ} / \mathrm{kg}$. This calculation means there is surplus energy produced by the system about $0.19 \mathrm{MJ} / \mathrm{kg}$.

According to the observation photobioreactor energy demand was fully supplied during microalgae cultivation. In this experiment Nannochloropsis oculata reach its peak growth in about 9 days with cell density ranged from 6-8 million cell/mL.

\section{Simulation results of the system}

Fig. 7 shows simulation results of the PVphotobioreactor system with full year meteorological data. It can be seen from the fluctuation of SOC that the system can supply the energy requirement of the system throughout the year. Eventhough, during rainy season the SOC significantly decreased, so the system can not supply the energy requirement with note if the load are constantly operated throughout the year. It means that PV panel capacity design using PSH value should be increased as well as battery capacity to ensure reliability of the system. 


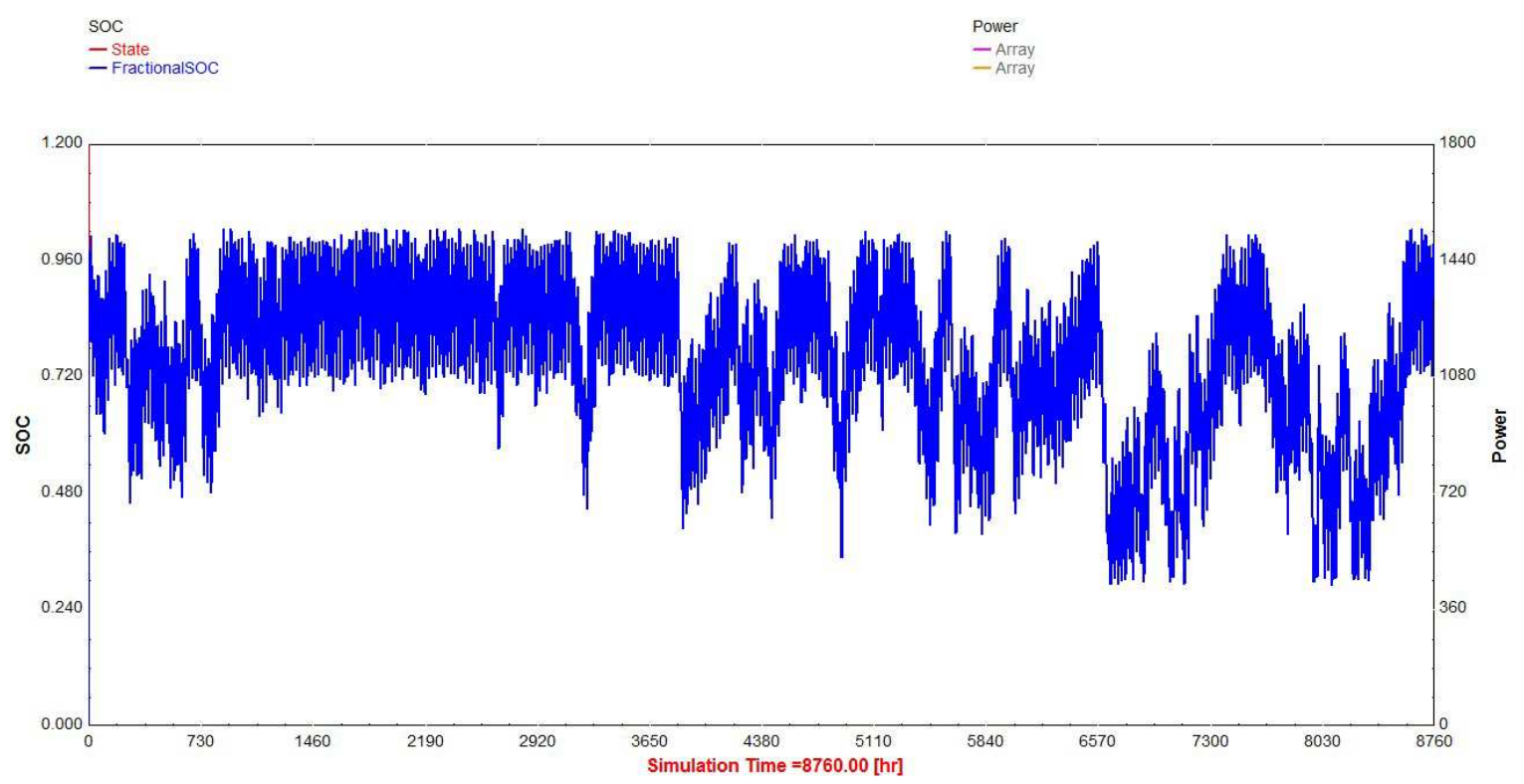

Fig. 7 SOC of battery of PV-Photobioreactor system

\section{IV.CONCLUSIONS}

Overall, PSH method for PV system design can be used for instant design of PV-Photobioreactor system. However, simulation results shows that if we could not predict exactly parameters value in PSH method formula the design could be under designed capacity as shown in the simulation results. Photobioreactor experiment result shows that Nannochloropsis oculata growth cycle reach it peak on between $10^{\text {th }}$ and $11^{\text {th }}$ day with fat content of $17.89 \%$ in the research. Nannochloropsis oculata has a potential fat content that can reach $30 \%$. So, controling microalgae growth parameters should be considered to achieve higher lipid content eventhough the energy requirement will be higher.

\section{ACKNOWLEDGMENT}

We would like to thank Directorate General of Higher Education of Indonesia who's funding this research under scheme of Institution Competitive Research Grant (PHBI Universitas Brawijaya) 2012.

\section{REFERENCES}

[1] Lubis, S. S. Studi Pengaruh Pencampuran Biodiesel Jarak Pagar Dengan Solar terhadap Perubahan karakteristik Fisikanya. Fisika. Universitas Sumatra Utara, Medan. 2008.

[2] Chisti, Y., 2007, Biodiesel from microalgae. Biotechnology Advances Vol. 25, pp. 294-306.

[3] Guschina IA, Harwood JL. Lipids and lipid metabolism in eukaryotic algae. Progress in Lipid Research 45: 160-186. 2006.

[4] Moazami, N., Ranjbar, R., Ashori, A., Tangestani, M., and Nejad, A.S. 2011. Biomass and lipid productivities of marine microalgae isolated from the Persian Gulf and the Qenshm Island. Biomass and Bioenergy 35, 1935-1939.

[5] Demirbas, A. (2008) "Comparison of Transesterification Methods for Production of Biodiesel from Vegetable Oils and Fats". Energy Conversion and Management, Vol. 49, hal. 125-130.

[6] D.F. Al Riza, S.I. Gilani and M.S. Aris, 2011b. Preliminary Investigation into the use of Solar PV Systems for Residential
Application in Bandar Sri Iskandar, Malaysia. Journal of Applied Sciences, 11: 2012-2017

[7] Hermanto, M. B., Sumardi, Hawa, L.C. and Fiqtinovri, S.M., 2011, Perancangan Bioreaktor untuk Pembudidayaan Mikroalga. Jurnal Teknologi Pertanian Vol 12, No. 3, pp 153-162.

[8] D.F. Al Riza, S.I. Gilani and M.S. Aris, 2011c, Measurement and Simulation of Standalone Solar PV System for Residential Lighting in Malaysia, Journal of Hydrocarbons Mines and Environmental Research Vol. 2, No. 1, pp 6-12.

[9] Andriyono, S. 2001. Pengaruh Periode Penyinaran Terhadap Pertumbuhan Isochrysis Galbana Klon Tahiti. Skripsi. IPB. Bogor. Hal 14-22

[10] Sutomo. (2005). Kultur Tiga Jenis Mikroalga (Tetraselmis sp., Chlorella sp.dan Chaetoceros gracilis) dan Pemgaruh Kepadatan Awal Terhadap Pertumbuhan C. Gracilis di Laboratorium. Oseanologi dan Limnologi di Indonesia. No. 37 :43-58. Pusat Penelitian Oseanografi.

[11] Fogg GE. 1987. Algal Cultures and Phytoplankton Ecology. The Univercityof Wiconsin Press, Medison.

[12] Elzenga, JTM, HBA. Prins, and J. Stefels. 2000.The Role Of Extracellular Carbonic Anhydrase Activity In Inorganic Carbon Utilization Of Phaeocystis Globosa (Prymnesiophyceae): A Comparison With Other Marine Algae Using The Isotopic Disequilibrium Technique. Limnology and Oceanography 45(2):372380

[13] Converti A, A.A.C. , EY. Ortiz, P. Perego,Del , and M .Borghi. 2009. Effect of temperature and nitrogen concentration on the growth and lipid content of Nannochloropsis oculata and Chlorella vulgaris for biodiesel production. Chemical Engineering and Processing: Process Intensification 48(6): 1146-1151

[14] De la Noue J and De Pauw N 1988 The potential of microalgal biotechnology: a review of production and uses of microalgae. Biotechnol. Adv. 6, 725-770.

[15] Fulks, W. And K.L. Main. (Eds).1991. The Design An Operation Of Commercial Scale Live Feed Production Systems In Rotifer And Microalgae System. The Oceanic Institute Makapuu Point. Honolulu Hawai. P. 3-52.

[16] Rizky NM. 2010. Optimasi Kultivasi Mikroalga Laut Nannochloropsis oculata dengan Perlakuan Pupuk Urea untuk Produksi Lemat Nabati. Fakultas Perikanan. Universitas Brawijaya. Malang

[17] Harsanto, S. dan S.R. Putra (2009), "Analisis Asam Lemak Mikroalga Nannochloropsis Oculata", Prosiding Seminar Nasional Kimia XI (SENAKI XI), Eds: Didik Prasetyoko, dkk., Institut Teknologi Sepuluh Nopember, Surabaya, hal. 210-217. 